\title{
PENANAMAN NILAI-NILAI RELIGIUS \\ DI MADRASAH ALIYAH NAHDLATUL WATHAN PANCOR LOMBOK TIMUR NUSA TENGGARA BARAT
}

\author{
${ }^{1)}$ Abd. Latif Manan, ${ }^{2}$ Sodiq A. Kuntoro, ${ }^{3)}$ Ajat Sudrajat \\ ${ }^{1)}$ IAI-Hamzanwadi Pancor Lombok Timur, ${ }^{2,3)}$ Universitas Negeri Yogyakarta \\ 1)abd.latifmanan@yahoo.co.id, ${ }^{3)}$ ajat@uny.ac.id
}

\begin{abstract}
Abstrak
Penelitian ini dimaksudkan untuk; (1) mengetahui dan mengkaji upaya penanaman nilainilai religius di Madrasah Aliyah Nahdlatul Wathan Pancor Lombok Timur; (2) menganalisis faktor-faktor penghambat pengembangan nilai-nilai religius di Madrasah Aliyah Nahdlatul Wathan Pancor Lombok Timur. Metode yang digunakan dalam penelitian ini adalah metode studi kasus dengan pendekatan kualitatif. Penelitian dilakukan di Madrasah Aliyah Nahdlatul Wathan Kelurahan Pancor Kabupaten Lombok Timur Provinsi Nusa Tenggara Barat. Data diperoleh melalui observasi, wawancara, dan dokumentasi. Teknik analisis data menggunakan reduksi data, display data, penarikan serta pengujian kesimpulan. Hasil penelitian menunjukkan bahwa: (1) Penanaman nilai-nilai religius di Madrasah Aliyah Nahdlatul Wathan Pancor ditempuh melalui beberapa upaya, yakni: (a) melalui kegiatan belajar mengajar di dalam kelas maupun di luar kelas melalui kegiatan keagamaan; (b) menggunakan berbagai strategi; serta (c) menjalin kerja sama sekolah dengan orang tua siswa; (2) faktor-faktor yang mempengaruhi penanaman nilai-nilai religius berasal dari faktor guru, siswa, dan orang tua siswa.
\end{abstract}

Kata kunci: nilai, religius, perilaku keagamaan siswa

\section{INCULCATING RELIGIOUS VALUES IN MADRASAH ALIYAH NAHDLATUL WATHAN PANCOR EAST LOMBOK}

${ }^{1)}$ Abd. Latif Manan, ${ }^{2}$ Sodiq A. Kuntoro, ${ }^{3)}$ Ajat Sudrajat

${ }^{1)}$ IAI-Hamzanwadi Pancor Lombok Timur, ${ }^{2,3)}$ Universitas Negeri Yogyakarta

1)abd.latifmanan@yahoo.co.id, ${ }^{3)}$ ajat@uny.ac.id

\begin{abstract}
This research is intended for: (1) knowing and reviewing the effort of inculcating religious values in Madrasah Aliyah Nahdlatul Wathan Pancor East Lombok; (2) analyzing the factors that hamper the Inculcating of religious values in Madrasah Aliyah Nahdlatul Wathan Pancor East Lombok. The method used in this research is case study method with qualitative approach. The research was conducted at Madrasah Aliyah Nahdlatul Wathan, Pancor Sub-District, East Lombok Regency, West Nusa Tenggara Province. Data were obtained through observation, interviews, and documentation. Data analysis techniques using data reduction, data display, and drawing and verifying conclusions. The results showed that: (1) inculcating of religious values in Madrasah Aliyah Nahdlatul Wathan Pancor taken through several efforts, namely: (a) through teaching and learning activities in the classroom or outside the classroom through religious activities; (b) using various strategies, and (c) establish school cooperation with parents of students; (2) factors influencing the inculcating of religious values are derived from teachers, students, and parents.
\end{abstract}

Keywords: values, religious, student's religious behavior 


\section{PENDAHULUAN}

Penanaman nilai-nilai religius di kalangan peserta didik di sekolah/madrasah, keluarga, maupun masyarakat, saat ini dipandang sangatlah penting. Pentingnya upaya tersebut dikarenakan saat ini terjadi pergeseran nilai-nilai di lingkungan keluarga dan masyarakat, sebagai akibat dari perkembangan teknologi informasi yang telah mempengaruhi nilai moral dan keagamaan yang selama ini menjadi pegangan dan berlaku di tengah-tengah masyarakat.

Berubahnya tatanan nilai moral dan keagamaan di tengah-tengah masyarakat dapat dilihat dari kenyataan-kenyataan yang terjadi seperti hilangnya rasa malu dan rasa takut masyarakat dalam melaksanakan hal-hal yang melanggar norma dan nilai-nilai yang ada di masyarakat. Perubahan-perubahan tersebut juga telah berpengaruh negatif terhadap siswa yang ditandai dengan meningkatnya angka kriminalitas di kalangan siswa seperti kasus narkoba, seks bebas hingga aborsi, dan perkelahian antarsiswa seperti yang terjadi di kotakota besar.

Berubahnya tatanan nilai moral dan keagamaan di tengah-tengah masyarakat dikhawatirkan akan membawa bangsa Indonesia ke ambang kehancuran. Lickona (1992, p. 13) menguraikan, terdapat sepuluh tanda perilaku manusia yang menunjukkan arah kehancuran suatu bangsa: (1) meningkatnya kekerasan di kalangan remaja; (2) ketidakjujuran yang membudaya; (3) semakin tingginya rasa tidak hormat kepada orang tua, guru dan figur pemimpin; (4) pengaruh per-group terhadap tindakan kekerasan; (5) meningkatnya kecurigaan dan kebencian; (6) penggunaan bahasa yang memburuk; (7) penurunan etos kerja; (8) menurunnya rasa tanggung jawab individu dan warga Negara; (9) meningginya perilaku merusak diri; dan (10) semakin kaburnya pedoman moral.

Dekadensi moral di era globalisasi dewasa ini, bila melihat apa yang disampaikan oleh Thomas Lickona tentang ciri penurunan moral sangat menghawatirkan. Keadaan ini tentunya sangat ironis bagi bangsa Indonesia yang telah memiliki berbagai sumber nilai moralitas yang dalam tatanan formal telah disepakati menjadi landasan kehidupan berbangsa dan bernegara yaitu Pancasila, yang seharusnya menjadi sumber dan pengendali tegaknya nilai-nilai moral bermasyarakat, berbangsa, dan bernegara. Nilai-nilai luhur universal yang terkandung dalam Pancasila, beserta berbagai landasan hukum yang kita miliki ternyata belum efektif untuk mengondisikan bangsa yang memiliki praktik hidup bermasyarakat secara santun dan bermartabat. Di samping itu, bangsa ini sebenarnya juga memiliki "klaim" sebagai bangsa yang religius. Akan tetapi religiusitas dari klaim itu belum mampu membuat para pemeluk agama untuk memiliki perilaku yang mencerminkan adanya kesalihan sosial, sehingga terjadi hubungan antarmanusia yang bersifat saling memberdayakan, saling menguntungkan, menonjolkan toleransi, empati, dan kejujuran, serta saling memagari dari perbuatan-perbuatan yang melawan sendi-sendi dan nilai-nilai moralitas kehidupan manusia sebagai makhluk Tuhan yang paling tinggi derajatnya di antara makhluk-makhluk yang lain di muka bumi ini.

Kalau demikian persoalannya, maka muncul pertanyaan, bagaimana peran pendidikan dewasa ini? Bagaimana kualitas pendidikan di Indonesia? Sebagai bangsa dengan penduduk muslim terbesar, kita tentu patut bertanya, bagaimana peran pendidikan Islam dalam memperbaiki kehidupan bangsa? Dan bagaimanakah pelaksanaan pendidikan agama (Islam) di sekolah/di madrasah guna membentuk manusia religius yakni manusia yang beriman dan bertakwa kepada Tuhan Yang Maha Esa serta patuh dan taat menjalankan perintah agama?

Berbagai kritik dilontarkan terhadap pelaksanaan pendidikan secara umum dan secara khusus di Indonesia karena fenomena penyimpangan perilaku tersebut dan kiranya dapat dijadikan indikator kurang berhasilnya upaya mencapai tujuan pendidikan nasional. Sutrisno (2012, p. 15) mengutarakan bahwa ada masalah dengan pendidikan di Indonesia, sementara Nata (2003, p. 220) menguraikan bahwa saat ini terdapat kesalahan landasan filosofis yang ditetapkan oleh pendidikan pada umumnya.

Realitas tersebut di atas mendorong pula timbulnya berbagai gugatan terhadap keefektifan pendidikan terutama pendidikan agama. Pendidikan agama yang berlangsung di sekolah/madrasah, dianggap kurang berhasil (untuk tidak mengatakan gagal) dalam menggarap sikap dan perilaku keberagamaan 
peserta didik serta membangun moral dan etika bangsa (Muhaimin, 2013, p. 31). Pendidikan agama dewasa ini juga dianggap belum mampu mencapai tujuan pendidikan nasional yakni untuk membentuk, mewarnai, dan mendukung tujuan pembangunan nasional, khususnya aspek pembangunan karakter dan spirit sumber daya manusia Indonesia yang bermartabat (Tolkhah, 2004, p. 113). Bahkan kemerosotan nilai-nilai moral yang melanda masyarakat saat ini tidak lepas dari ketidakefektifan penanaman nilai-nilai moral, baik di sekolah maupun di masyarakat secara keseluruhan (Sauri\& Nurdin, 2009, p. 19).

Berbagai faktor serta persoalan yang terjadi pada pendidikan Islam saat ini yang ditenggarai menjadi penyebab kurang efektifnya pendidikan agama di sekolah/madrasah, dikarenakan pendidikan agama kurang bisa mengubah pengetahuan agama yang kognitif menjadi "makna" dan "nilai" atau kurang mendorong penjiwaan terhadap nilai-nilai keagamaan yang perlu diinternalisasikan dalam diri peserta didik. Dengan kata lain, pendidikan agama selama ini lebih menekankan pada aspek knowing dan doing dan belum banyak mengarah kepada aspek being, yakni bagaimana peserta didik menjalani hidup sesuai dengan ajaran dan nilai-nilai agama yang diketahui (knowing), padahal inti pendidikan agama berada di aspek ini (Muhaimin, 2013. p. 31).

Oleh karena itu, guna mengatasi berbagai persoalan yang terjadi pada pendidikan agama dalam upaya menanamkan nilai-nilai religius memerlukan berbagai pendekatan, strategi, dan metode pengajaran yang berbeda dari pendekatan pelajaran yang lain. Berbagai pendekatan, strategi, dan metode yang digunakan diharapkan tidak hanya berpengaruh pada peningkatan penguasaan materi tentang ajaran agama semata, tetapi juga pada penanaman komitmen beragama yang dapat membentuk perilaku, sikap hidup, dan gaya hidup individu serta kelompok sosial yang sesuai dengan nilai-nilai agama.

Ajat (2011, p. 23) menguraikan bahwa untuk menanamkan nilai-nilai religius pada diri peserta didik dan membawa peserta didik menjadi manusia religius yakni manusia yang beriman dan bertakwa kepada Allah Swt. dapat dilakukan dengan berbagai pendekatan yang lebih rasional dan kreatif. Pendekatan yang semata-mata sifatnya doktrinal dalam menyampaikan ajaran agama tampaknya harus diubah dan diperbaharui, karena kesan yang diterima dari cara-cara yang doktrinal hanya menempatkan peserta didik sebagai objek yang pasif dan keharusan menerima setiap ajaran agama tanpa melibatkan emosi dan intelektualnya.

Sementara itu, menurut Kuntoro (2008, p. 1), pendidikan diharapkan bersifat humanis-religius dimana dalam pengembangan kehidupan (ilmu pengetahuan) tidak terlepas dari nilai-nilai keagamaan dan kebudayaan. Pendidikan diharapkan tidak terlepas dari nilai-nilai kemanusiaan dan keagamaan. Pendidikan dituntut untuk ikut mengembangkan kehidupan keberagamaan, yakni kegiatan pendidikan yang bertujuan untuk mengembangkan nilai-nilai kemanusiaan dan nilai religius atau keberagamaan peserta didik.

Oleh karena itu, upaya penanaman nilai-nilai religius di sekolah/madrasah dapat dilakukan melalui beberapa strategi yang dapat dilakukan, baik itu dilakukan di dalam kelas melalui proses pembelajaran dan di luar kelas melalui kegiatan keagamaan (Tafsir, 2012, p. 229). Penanaman nilai-nilai religius dapat juga dilakukan dengan cara memberikan contoh sikap dan tingkah laku yang baik serta membiasakan siswa berakhlak mulia, beribadah, dan disiplin, sehingga dalam hal ini, harus dilaksanakan dengan melibatkan peran aktif orang tua/keluarga anak didik (Duryat, 2013, p. 110).

Selanjutnya, pembentukan sikap mental peserta didik ke arah menumbuhkan kesadaran beragama, dapat diupayakan dengan menciptakan suasana religius yang kental di lingkungan pendidikan yang meliputi tata pergaulan, pakaian, lingkungan sekolah, praktik ibadah, dan lainnya, karena pada dasarnya beragama tidak hanya pada kawasan pemikiran saja, tetapi juga memasuki kawasan rasa, karena itulah sentuhan-sentuhan emosi beragama perlu dikembangkan (Daulay, 2001, p. 42).

Kegiatan-kegiatan tersebut di atas, dilaksanakan sebagai upaya untuk menanamkan nilai-nilai religius di kalangan peserta didik, sehingga peserta didik menjadi manusia yang religius. Adapun gambaran karakter manusia religius tersebut di antaranya; (1) memiliki komitmen terhadap perintah dan larangan agama, (2) bersemangat mengkaji ajaran agama, (3) aktif dalam kegiatan keagamaan, (4) menghargai simbol-simbol keagamaan, (5) 
akrab dengan kitab suci, (6) mempergunakan pendekatan agama dalam menentukan pilihan, dan (7) ajaran agama dijadikan sebagai sumber pengembangan ide (Alim, 2006, p. 12).

Melalui kegiatan tersebut, diharapkan pula dapat meningkatkan keimanan dan ketakwaan peserta didik terhadap Allah Swt. serta menanamkan rasa cinta kepada Nabi dan Rasul-Nya, dapat melaksanakan ibadah-ibadah salat baik fardhu maupun yang sunnah, dapat membaca Alquran dengan baik dan benar, serta juga diharapkan bisa menjadi manusia yang bisa menjalin hubungan baik dengan sesama makhluk ciptaan Tuhan serta dapat mengaplikasinnya dengan baik di mana pun baik di rumah maupun di lingkungan sekitar tempat tinggalnya.

Sehingga melalui Pendidikan religius, nilai-nilai agama secara umum dapat diajarkan pada peserta didik, apapun agamanya. Pendidikan religius penuh dengan muatan nilai moral. Pendidikan religius diharapkan menjadi salah satu ruh pendidikan di Indonesia. Hal tersebut sejalan dengan falsafah pendirian negara Republik Indonesia yang tertuang dalam dasar negara, yakni pancasila. Sila-sila yang terkandung dalam Pancasila merupakan cerminan dari kepribadian bangsa Indonesia.

Kajian tersebut di atas menarik untuk ditelaah, sebab untuk dapat menanamkan dan mewariskan nilai-nilai luhur terutama nilai agama pada anak didik tidak mudah untuk dilaksanakan. Dalam pelaksanaannya dihadapkan pada banyak tantangan baik yang datang dari subjek sasaran maupun dari pihak yang ingin menanamkan dan mewariskan nilai-nilai agama tersebut. Untuk itulah, upaya penanaman nilai-nilai religius yang selama ini dilaksanakan di sekolah/madrasah penting untuk dikaji, sehingga penulis tertarik untuk mengkaji tentang "Penanaman Nilai-Nilai Religius di Sekolah/Madrasah".

\section{METODE PENELITIAN}

Metode yang digunakan dalam penelitian ini adalah metode studi kasus dengan pendekatan kualitatif. Penelitian kualitatif adalah penelitian yang mengeksplorasi sikap, perilaku, dan pengalaman yang diperoleh melalui metode wawancara atau focus group (Dawson, 2010: p. 15). Selanjutnya Moleong (2001, p. 3) mendefinisikan pendekatan kuali- tatif sebagai prosedur penelitian yang menghasilkan data deskriptif berupa kata-kata tertulis atau lisan dari orang-orang dan perilaku yang dapat diamati, selanjutnya pendekatan ini diarahkan pada latar dan individu tersebut secara holistic (utuh).

Terkait dengan pendekatan studi kasus, Sevilla, Ochave, Punsalan, Regala, \& Uriarte, (1993, p. 74) menguraikan bahwa pendekatan studi kasus yang bersifat prospektifkualitatif sangat berguna untuk meneliti, mencari kesimpulan dan menemukan pola kecendrungan serta arah lain yang dapat digunakan dalam membuat dugaan-dugaan pertumbuhan dan perkembangan di masa yang akan datang. Melalui pendekatan kualitatif, peneliti mencoba memperoleh informasi yang mendalam dari para partisipan sehingga sikap, perilaku dan pengalaman partisipan dapat dieksplorasi dan peneliti dapat mendeskripsikan upaya penanaman nilai-nilai religius di Madrasah Aliyah Nahdlatul Wathan Pancor Lombok Timur, perilaku keagamaan siswa serta faktorfaktor yang memengaruhi upaya tersebut.

Selanjutnya, penelitian dilaksanakan di Madrasah Aliyah Nahdlatul Wathan Kelurahan Pancor Kabupaten Lombok Timur Provinsi Nusa Tenggara Barat. Lokasi ini diambil dengan berbagai pertimbangan: (1) Madrasah ini berada dilingkungan Ponpes Nahdlatul Wathan. Ponpes ini merupakan ponpes yang terbesar di Nusa Tenggara Barat, (2) Sistim Pendidikannya menggunakan perpaduan kurikulum Nasional dan Kurikulum Madrasah (KURMA). Adapun Subjek sekaligus yang akan menjadi responden yakni Pengurus Yayasan, Kepala madrasah, Wakil Kepala Madrasah, Pembina OSIS, Guru-guru yang memegang rumpun mata pelajaran PAI, Siswa, dan Orang tua/wali siswa.

Dalam memperoleh data, peneliti mengunakan wawancara mendalam (in-depth interview), observasi dan dokumentasi. Boyce (2006, p. 2) menjelaskan bahwa in-depth interview (wawancara mendalam) adalah teknik dalam penelitian kualitatif yang dilakukan secara intensif dengan sejumlah kecil responden untuk mengeksplorasi perspektif mereka mengenai ide, program, atau situasi tertentu. Pada metode ini, peneliti dan responden berhadapan langsung (face to face) untuk mendapatkan informasi secara lisan dengan tujuan mendapatkan data yang dapat menjelaskan permasalahan penelitian. 
Wawancara dilaksanakan untuk memperoleh data utama berupa ucapan, buah pikiran, pandangan dan perasaan serta tindakan dari subjek penelitian. Setelah peneliti memperoleh keterangan, peneliti mengadakan wawancara yang lebih mendalam dan disusun berdasarkan apa yang disampaikan oleh subjek penelitian, dengan istilah lain. Adapun wawancara yang dilakukan adalah wawancara mendalam, yang dilakukan dengan mengajukan pertanyaan-pertanyaan terbuka, yang memungkinkan responden memberikan jawaban secara luas. Data pertama bersifat non-directive menurut pikiran dan perasaan subjek penelitian. Sedangkan data yang bersifat directive ditinjau dari sudut pandang peneliti, sehingga wawancara beralih dari tidak terstruktur menjadi lebih terstruktur.

Selanjutnya, terdapat jenis-jenis masalah tertentu yang tidak dapat dijangkau oleh metode wawancara. Adakalanya penting untuk melihat perilaku dalam keadaan (setting) alamiah, melihat dinamika, melihat gambaran perilaku berdasarkan situasi yang ada. Dalam hal ini observasi menjadi penting sebagai metode utama untuk mendapatkan informasi. Dalam penelitian ini, peneliti tidak terlibat langsung dalam kegiatan di madrasah namun hanya melakukan pengamatan, yang demikian itu disebut dengan observasi non partisipan (Putro, 2012, p. 48).

Hal ini dilakukan untuk mendapatkan data yang valid tentang strategi yang dilakukan dalam upaya menanamkan nilai-nilai religius pada siswa didik. Melalui observasi, peneliti melihat objek penelitian secara langsung dengan mengamati kegiatan proses belajar mengajar, menggambarkan dan memberikan catatan terhadap objek penelitian, melakukan pengamatan atas aktivitas-aktivitas yang terjadi di Madrasah Aliyah NW Pancor, mengamati kegiatan-kegiatan yang dilaksanakan, mengamati prilaku warga madrasah serta aktivitas lainya di sekitar madrasah.

Selanjutnya, untuk melengkapi data yang sudah ada, peneliti melengkapinya dengan dokumen-dokumen yang diperoleh di madrasah. Peneliti mengumpulkan data yang diambil dari catatan-catatan yang erat hubungannya dengan objek yang diteliti. Dokuemtasi ini digunakan untuk memperoleh data-data yang tidak bisa diungkap oleh metode yang lainnya. Dalam pelaksanaannya penulis meli- hat arsip-arsip dan catatan-catatan miliki madrasah yang diperlukan.

Terkait dengan Keabsahan data, dalam penelitian ini didasarkan pada empat kriteria yaitu derajat kepercayaan (credibility), keteralihan (transferability), kebergantungan (dependabiliti), dan kepastian (confirmabiliti). Sementara analisis data yang digunakan oleh peneliti mengacu pada teknik analisis interaktif yang ditawarkan oleh Miles \& Huberman (1994). Teknik analisis ini pada dasarnya terdiri dari tiga komponen: reduksi data (data reduction), penyajian data (data display), dan penarikan serta pengujian kesimpulan (drawing and verifying conclusions).

\section{HASIL PENELITIAN DAN PEMBAHASAN}

Berikut diuraikan beberapa upaya yang dilakukan untuk menanamkan nilai-nilai religious di Madrasah Aliyah NW Pancor.

\section{Melalui Proses Belajar Mengajar di Kelas.}

Pendidikan adalah usaha sadar dan terencana untuk mewujudkan suasana belajar dan proses pembelajaran, ini berarti pendidikan di sekolah bukanlah proses yang dilaksanakan secara asal-asalan, akan tetapi proses yang bertujuan sehingga segala sesuatu yang dilakukan guru dan siswa diarahkan pada pencapaian tujuan tertentu. Proses pendidikan yang terencana itu diarahkan untuk mewujudkan proses pembelajaran. Selanjutnya, Wina (2008, p. 3) menguraikan bahwa hasil akhir dari proses pembelajaran adalah kemampuan peserta didik memiliki kekuatan spiritual keagamaan, pengendalian diri, kepribadian, kecerdasan, akhlak mulia, serta keterampilan yang diperlukan dirinya, masyarakat, bangsa, dan negara. Ini berarti proses pembelajaran berujung pada pembentukan sikap, pengembangan kecerdasan atau intelektual, serta pengembangan keterampilan anak sesuai dengan kebutuhan. Ketiga aspek ini harus berkembang secara harmonis serasi dan selaras.

Pendidikan Agama Islam (PAI) merupakan sebuah mata pelajaran yang tidak terpisahkan dari kurikulum, sehingga PAI merupakan alat untuk mencapai salah satu aspek kompetensi tamatan sekolah/madrasah. Secara khusus PAI ini didesain dan diberikan kepada siswa yang beragama Islam dalam rangka meningkatkan keberagamaan mereka (Pasal 37 ayat 1 Undang-Undang Nomor 20 
tahun 2003 tentang Sistem Pendidikan Nasional). Dengan fungsi ini, PAI diharapkan dapat mengantarkan peserta didik memiliki karakteristik sosok muslim yang diidealkan, yakni memiliki tingkat keberagamaan tertentu.

Untuk mengantarkan peserta didik agar memiliki karakteristik sosok muslim yang diidealkan maka dalam hal ini, guru bidang studi Pendidikan Agama Islam merupakan sosok yang secara langsung mempunyai tugas utama dalam upaya menanamkan nilainilai religius pada peserta didik. Guru bidang studi Pendidikan Agama Islam harus mempunyai rencana atau strategi dalam rangka memberikan pengetahuan tentang nilai-nilai religius bagi siswa melalui materi Pendidikan Agama Islam di dalam kelas dengan secara teoritis dan terperinci.

Rumpun materi Pendidikan Agama Islam secara umum terdiri dari mata pelajaran Akidah Akhlak, Fikih, Alquran Hadis, Sejarah Kebudayaan Islam (SKI), sehingga esensi dari materi PAI itu sendiri meliputi tiga bagian materi, yakni materi yang berkenaan dengan iman, islam dan ihsan. Sebagaimana tertera pada Pedoman Khusus pengembangan PAI yang dikeluarkan oleh Depdiknas, prinsip dasar pengembangan materi PAI meliputi 3 kerangka, yaitu akidah, syariah, dan akhlak. Sehingga apa pun aktivitas pembelajaran yang diupayakan guru, aktivitas-aktivitas pembelajaran tersebut haruslah mampu memfasilitasi pembentukan dan perkembangan peserta didik.

Penanaman nilai-nilai religius (nilai akidah, syariah dan akhlak) melalui proses belajar mengajar di kelas secara normatif diberikan melalui rumpun materi Pendidikan Agama Islam yang terdiri dari mata pelajaran Akidah Akhlak, Fikih, Alquran Hadis, dan Sejarah Kebudayaan Islam (SKI). Sedang secara aplikatif, penanaman nilai-nilai religius dilakukan melalui kegiatan pembelajaran yang dilaksanakan setiap hari yang sarat dengan nilai-nilai akidah, syariah dan akhlak.

\section{Melalui Kegiatan Keagamaan di luar kelas.}

Upaya penanaman nilai-nilai religius di lingkungan sekolah/madrasah tidak hanya dilakukan di dalam kelas melalui kegiatan belajar mengajar semata, tetapi diupayakan pula dilakukan di luar kelas melalui kegiatan keagamaan. Kegiatan keagamaan merupakan program kegiatan yang berusaha memperta- hankan, melestarikan dan menyempurnakan umat manusia agar mereka tetap beriman kepada Allah Swt. dengan menjalankan syariat Islam sehingga menjadi manusia yang hidup bahagia di dunia dan akhirat kelak. Melalui kegiatan keagamaan di lembaga pendidikan diharapkan pula dapat memberikan inspirasi, motivasi, dan stimulasi bagi siswa agar potensi siswa berkembang dan dapat diaktifkan secara maksimal, menambah ilmu pengetahuan agama Islam dan menjalin silaturrahmi (Syukir, 1983, p. 20).

Kegiatan keagamaan yang dilaksanakan di lingkungan sekolah/madrasah, bertujuan untuk memperkaya dan memperluas wawasan pengetahuan dan kemampuan yang telah dimiliki oleh peserta didik dari berbagai bidang studi yang telah diajarkan. Sehingga kegiatan ini diharapkan dapat semakin meningkatkan keimanan serta ketaqwaan siswa terhadap Allah Swt. serta rasa cinta kepada Nabi dan Rasul-Nya, dapat melaksanakan ibadah-ibadah salat, baik fardlu maupun yang sunah. Melalui kegiatan keagamaan ini pula, peserta didik diharapkan bisa menjadi manusia yang bisa menjalinkan hubungan baik dengan sesama makhluk, memiliki akhlak yang baik serta dapat mengaplikasikannya dengan baik di manapun baik di rumah maupun di lingkungan sekitar tempat tinggal.

Kegiatan keagamaan yang dapat diselenggarakan di sekolah/madrasah di antaranya dengan melaksanakan kegiatan membaca Alquran, salat Duha, salat Zuhur berjamaah, pelaksanaan Peringatan Hari Besar Islam (PHBI), dan pengkajian kitab kuning.

\section{Menerapkan berbagai Pendekatan.}

Untuk menunjang kegiatan tersebut di atas, upaya menanamkan nilai-nilai religius juga dilakukan dengan menggunakan beberapa pendekatan. Adapun pendekatan-pendekatan tersebut sebagai berikut.

Pertama, dengan meningkatkan disiplin beribadah siswa. Ibadah merupakan perilaku manusia yang dilakukan atas perintah Allah Swt. dan dicontohkan oleh Rasulullah saw. atau disebut ritual seperti salat, zakat, puasa dan sebagainya. Beribadah berarti melaksanakan semua perintah Tuhan sesuai dengan kemampuan dan meninggalkan seluruh larangan-Nya dengan niat yang ikhlas. Unsur niat dan kesengajaan merupakan salah satu 
penentu berpahala tidaknya perbuatan dan tingkah laku sehari-hari. Kegiatan keagamaan apabila tidak disertai dengan kesadaran beragama bukanlah ibadah. Sebaliknya tingkah laku sosial dan pekerjaan sehari-hari, apabila disertai dengan niat kepada Allah adalah termasuk ibadah.

Meningkatkan disiplin beribadah siswa pada dasarnya dilaksanakan karena kegiatan ibadah kepada Allah Swt. merupakan suatu hal yang sangat penting. Dengan meningkatkan displin beribadah siswa, diharapkan dapat membentuk siswa yang berkarakter dan sadar diri untuk senantiasa beribadah kepada Allah Swt. dan menjalankan segala perintah-Nya sesuai dengan norma-norma agama, mampu melaksanakan salat tepat waktu dan juga melaksanakan tata cara salat dengan baik, baik dalam rukun-rukun salatnya maupun sunah-sunah salatnya.

Kedua, Keteladanan dalam pembentukan Akhlaqul Karimah siswa. Di sekolah/ madrasah seorang anak pada dasarnya mendapatkan pengajaran dan pendidikan agama dari guru Pendidikan Agama Islam. Peran guru Pendidikan Agama Islam menjadi sangat penting karena akan sangat membantu dalam pertumbuhan kepribadian peserta didik terutama dari segi penanaman akhlaqul karimah. Karena itulah, seorang guru dapat menjadi tokoh idola dan panutan yang akan diteladani oleh peserta didik di sekolah ataupun di madrasah. Dengan keteladanan ini, seorang guru akan mampu membimbing untuk pembentukan sikap yang kokoh.

Pendidikan dengan keteladanan merupakan bentuk pendidikan yang dilakukan dengan memberi contoh, baik berupa tingkah laku, sifat, cara berfikir, dan sebagainya. Banyak para ahli yang berpendapat bahwa pendidikan keteladanan merupakan metode yang paling berhasil dan berguna serta merupakan salah satu cara yang efektif dalam mempersiapkan dan membentuk anak yang memiliki moral, spiritual dan sosial yang matang. Hal ini disebabkan, dalam belajar manusia pada umumnya lebih mudah menangkap yang kongkrit ketimbang yang abstrak, akhlak yang baik tidak dapat dibentuk hanya dengan pelajaran, instruksi dan larangan, serta secara psikologis manusia memang memerlukan tokoh teladan dalam hidupnya, senang meniru tanpa mempertimbangkan dampaknya. Karena itulah di dalam metode ini seorang guru di- upayakan untuk menjadi top figur bagi anak didiknya.

Ketiga, Pembiasaan dalam beribadah. Pembiasaan merupakan bagian penting dalam tahapan peserta didik untuk mulai bersosialisasi, berinteraksi sosial di lingkungan sekolahnya. Oleh karena itu, peran guru sebagai pengganti orang tua yang berada di sekolah sangat dibutuhkan dalam mengembangkan pembiasaan berperilaku yang dikehendaki (misalnya disiplin, tertib, menghargai sesama, dan mencintai sesama makhluk ciptaan Tuhan) melalui contoh dan tindakan nyata.

Pembiasaan dapat diartikan sebagai suatu perbuatan atau keterampilan tertentu secara terus-menerus dan konsisten untuk waktu yang cukup lama, sehingga perbuatan atau keterampilan itu benar-benar dan akhirnya menjadi kebiasaan yang sulit ditinggalkan. Pembiasaan adalah ulangan perbuatan yang sama. Kebiasaan terbentuk karena adanya sesuatu yang dibiasakan, sehingga akan menjadi sesuatu yang sulit ditinggalkan (Zubair, 1995, p. 63).

Dalam kaitannya dengan metode pengajaran dalam pendidikan Islam, dapat dikatakan pembiasaan adalah sebuah cara yang dapat dilakukan untuk membiasakan anak didik berfikir, bersikap dan bertindak sesuai dengan tuntutan ajaran agama Islam (Maunah, 2009, p.93). Sedangkan pembiasaan terbentuk melalui pengulangan dan memperoleh bentuknya yang tetap apabila disertai dengan kepuasan. Anak yang sering mendengar orang tuanya mengucapkan nama Allah, umpamannya, akan mulai mengenal nama Allah.

Jadi pembiasaan di sini merupakan hal-hal yang sering dilakukan secara berulang-ulang dan merupakan puncak perwujudan dari tingkah laku yang sesungguhnya. Ketika seseorang telah memiliki kemampuan untuk mewujudkan lewat tindakan dan apabila tindakan ini dilakukan secara terus-menerus, maka ia akan menjadi kebiasaan, dan kebiasaan tersebut akan mewujudkan karakter. Adapun pembiasaan yang dimaksud penulis maksudkan adalah pembiasaan dalam menjalankan ajaran Islam, sehingga nilai-nilai yang ada pada pembiasaan yang dilakukan dapat dimiliki dan tertanam dengan baik atau nilainilai tersebut dapat terinternalisasi dan dapat menjadi suatu karakter.

Keempat, Menegakkan aturan-aturan dan tata tertib sekolah/madrasah. Sekolah ada- 
lah salah satu lembaga yang bertugas untuk membentuk kepribadian siswa. Sekolah merupakan tempat terjadinya proses pendidikan untuk menciptakan sumber daya manusia yang diharapkan, manusia yang berkualitas. Sekolah juga bertugas membentuk kepribadian siswa agar mempunyai kepribadian yang luhur, mulia serta berdisiplin tinggi. Sekolah menengah atas sebagai salah satu lembaga pendidikan formal merupakan sekolah yang sangat berpengaruh terhadap pembentukan pribadi siswa. Sesuai dengan kenyataan sehari-hari dijumpai siswa yang tidak disiplin dan menyimpang dari norma. Permasalahan-permasalahan tersebut tentu akan mengganggu proses belajar-mengajar.

Untuk mengatasi permasalahan tersebut dibentuklah suatu peraturan yang berfungsi untuk membentuk kedisiplinan yaitu tata tertib sekolah. Berkenaan dengan disiplin, Arikunto (2009, p. 114) mengemukakan bahwa disiplin merupakan kepatuhan seseorang dalam mengikuti peraturan dan tata tertib karena di dorong oleh adanya kesadaran yang ada di hatinya.

Sementara itu, tujuan disiplin sekolah, adalah: (1) memberi dukungan bagi terciptanya perilaku yang tidak menyimpang, (2) mendorong siswa melakukan yang baik dan benar, (3) membantu siswa memahami dan menyesuaikan diri dengan tuntutan lingkungannya dan menjauhi melakukan halhal yang dilarang oleh sekolah, dan (4) siswa belajar hidup dengan kebiasaan-kebiasaan yang baik dan bermanfaat baginya serta lingkungannya (Rachman, 1999, p. 83). Karena pada dasarnya sekolah adalah sumber disiplin dan tempat berdisiplin untuk mencapai ilmu pengetahuan yang dicita-citakan (Soemarmo, 1998, p. 67).

Di dalam tata tertib tersebut diatur mengenai hak dan kewajiban siswa, larangan, dan sanksi-sanksi. Karena itulah, seorang siswa dalam mengikuti kegiatan belajar di sekolah tidak akan lepas dari berbagai peraturan dan tata tertib yang diberlakukan di sekolahnya, dan setiap siswa dituntut untuk dapat berperilaku sesuai dengan aturan dan tata tertib yang berlaku di sekolahnya.

Dalam hal tata tertib, komponen yang ada di sekolah/madrasah sebagai suatu ikatan atau aturan yang harus dipatuhi setiap warga sekolah tempat berlangsungnya proses belajar mengajar. Penegakan aturan/tata tertib me- rupakan cara yag dapat ditempuh agar semua siswa taat dan patuh pada peraturan-peraturan yang berlaku dalam rangka membentuk kedisiplinan siswa, sebab siswa yang mempunyai disiplin yang tinggi akan membentuk karakter yang baik.

Manfaat lain dari upaya penegakan aturan/tata tertib di sekolah/madrasah, agar siswa mampu belajar hidup dengan kebiasaankebiasaan yang baik yang bermanfaat baginya beserta lingkungannya, sehingga di lingkungan tersebut, secara khusus dapat tercipta keamanan dan lingkungan belajar yang nyaman terutama di kelas. Tentunya apabila ada sekolah tanpa tata tertib, akan muncul perilaku yang tidak tertib, tidak teratur, tidak terkontrol, dan perilaku liar, yang pada gilirannya akan mengganggu kegiatan pembelajaran selain itu suasana kondusif yang dibutuhkan dalam pembelajaran juga menjadi terganggu.

Sebagaimana diuraikan oleh Arikunto (2009, p. 121) bahwa tanpa adanya peraturan dan tata tertib, kegiatan sekolah tidak akan efisien, karena pada dasarnya peraturan dan tata tertib merupakan dua hal yang sangat penting bagi kehidupan sekolah. Selanjutnya pihak sekolah/madrasah juga menyadari, bahwa agar supaya pelaksanaan penegakan aturan/tata tertib dapat berjalan efektif maka dibutuhkan kerja sama beberapa orang guru, sehingga sekolah/madrasah dapat mengontrol siswa terkait perilaku kesehariannya di sekolah yang bertujuan mengarahkan siswa agar selalu berada pada koridor tata tertib dan mencegah terjadinya pelanggaran serta penyimpangan perilaku dari siswa.

Kelima, pemberian reward dan punishment. Sebagaimana telah diuraikan terdahulu, dalam proses pendidikan menyeragamkan perilaku anak dan membawa mereka ke arah yang lebih baik bukan hal mudah. Seorang pendidik akan merasa kesulitan untuk membangkitkan kesadaran anak melakukan hal baik secara terus menerus, karena bagi anak tidak akan ada keuntungan yang mereka peroleh dengan melakukan hal tersebut. Sementara meminta mereka untuk tidak berbuat kesalahan atau sesuatu tidak baik dan bisa merugikan juga terasa sulit, dikarenakan mereka tidak mendapat contoh yang benar untuk memperbaiki kesalahan mereka, hanya keluhkesah dan larangan saja yang umum dan akrab di telinga mereka. 
Untuk itu perlu adanya strategi khusus yang bisa menjadikan anak lebih termotivasi dan berbuat lebih baik lagi di dalam proses pendidikan yang membawanya ke arah perubahan yang lebih baik. Strategi tersebut berupa pemberian reward (ganjaran) dan $p u$ nishment (hukuman) dalam proses pendidikan.

Reward merupakan hadiah, pembalas jasa, alat pendidikan yang diberikan kepada siswa yang telah mencapai prestasi baik (Pradja, 1978, p. 169) dan merupakan hal yang menggembirakan bagi anak, dan dapat menjadi pendorong atau motivasi bagi belajarnya murid (Indrakusuma, 2002, p. 147). Pemberian reward bertujuan untuk memberikan motivasi kepada siswa, agar dapat melakukan perbuatan terpuji dan berusaha untuk meningkatkannya. Motivasi itu sendiri adalah keadaan dalam pribadi orang yang mendorong individu yang melakukan aktivitas-aktivitas tertentu untuk mencapai suatu tujuan (Suryabrata, 2005, p. 70).

Sementara itu, hukuman (punisment) merupakan tindakan pendidikan terhadap anak didik karena melakukan kesalahan, dan dilakukan agar anak didik tidak lagi melakukannya (Tanlain, 2006, p. 57). Maksud dari pemberian hukuman (punishment) itu sendiri yakni memberikan penderitaan yang diberikan atau ditimbulkan dengan sengaja oleh seseorang (orang tua, guru, dan sejajarnya) sesudah terjadi suatu pelanggaran, kejahatan, atau kesalahan (Purwanto, 2005, p. 186).

Dari uraian tersebut di atas, pemberian reward dan punishment dimaksudkan untuk membuat anak lebih giat dan lebih termotivasi lagi di dalam melaksanakan kegiatan-kegiatan atau proses pembelajaran di sekolah/madrasah. Siswa diberikan reward supaya siswa cenderung mengulangi perbuatan yang membuatnya diberikan reward. Sementara punishment diberikan oleh guru kepada siswa karena siswa melakukan pelanggaran atau kesalahan dan membuat siswa menyesali perbuatannya yang salah itu. Misalnya ketika ada siswa yang pernah mendapat hukuman karena tidak mengerjakan tugas atau melakukan pelanggaran-pelanggaran yang cukup berat, maka ia akan berusaha untuk tidak memperoleh hukuman lagi.

Pemberian reward dan punishment penting diterapkan, karena substansi reward dan punishment dalam metode pembelajaran sebenarnya adalah sebuah bentuk respon sese- orang karena perbuatannya. Pemberian ganjaran merupakan respon yang positif, sedangkan pemberian hukuman adalah respon negatif, keduanya memiliki tujuan yang sama, yaitu ingin mengubah tingkah laku anak ke arah yang lebih baik sebagai motivasi belajar. Namun penerapan punishment dilakukan ketika benar-benar diperlukan dan itupun dilakukan dengan sangat hati-hati dan penuh pertimbanganserta dilakukan secara terbatas dan tidak menyakiti anak.

\section{Menjalin Kerja sama Antara Sekolah/Madrasah dan Orang Tua}

Usaha pendidikan keimanan memang hanya sedikit sekali yang dapat dilakukan di sekolah. Padahal penanaman iman itu adalah inti pendidikan agama dan iman memang inti agama. Maka dalam hal ini orang tua harus berperan aktif di dalam menyelenggarakan pendidikan keimanan di rumah tangga. Dalam hal penanaman iman ini, sekalipun guru ingin berperan banyak, ia tidak mungkin mampu memainkan peran ini. Ini pun menjadi dasar yang kuat perlunya kerja sama antara orang tua di rumah dan guru di sekolah. Yang memerlukannya sebenarnya bukan guru atau sekolah, melainkan orang tuanya. Orang tua dalam kehidupan keluarga merupakan tempat pendidikan pertama dan utama bagi anak atau siswa memperoleh pendidikan dan pembelajaran termasuk pembinaan akhlak, sehingga keberadaannya memiliki peran dan fungsi strategis dalam meningkatkan pendidikan dan prestasi belajar anak baik dalam bidang kognitif, afektif dan psikomotorik (Tafsir, 2009, p. 128)

Akan tetapi yang menjadi persoalan yaitu tidak semua orang tua mengetahui apa yang sebaiknya dilakukan di rumah dalam rangka menanamkan nilai-nilai religius bagi putra putri mereka. Sebagaimana diuraikan oleh Tafsir (2009, p.128) bahwa terkadang orang tua terlambat menyadari perlunya kerja sama ini. Maka sekolah diharapkan mengambil inisiatif untuk menjalin kerja sama itu. Setelah kerja sama terjalin, selanjutnya mengenai apa yang mesti dilakukan dapat dirancang bersama orang tua dan guru agama.

Hal ini sepertinya dipahami pula oleh pihak sekolah/madrasah, karena itulah diupayakan menjalin selalu kerja sama antara sekolah/madrasah dengan orang tua siswa. Untuk mewujudkan kerja sama ini, pihak 
sekolah/madrasah melakukan beberapa langkah-langkah yang diakukan, agar tidak terjadi kontradiksi atau ketidaksesuaian antara nilainilai yang harus dipegang teguh oleh anakanak di sekolah dengan yang harus mereka ikuti di lingkungan keluarga atau masyarakat, sebab apabila terjadi konflik nilai, anak-anak akan merasa bingung sehingga tidak memiliki pegangan nilai yang menjadi acuan dalam berperilaku. Akibatnya, mereka tidak mampu mengontrol diri dalam menghadapi pengaruh pengaruh negatif dari lingkungan sekitar mereka.

Mengingat penanaman nilai-nilai religius selain efektif dilakukan di sekolah/ madrasah tetapi penanaman nilai yang dilakukan orang tua di rumah juga sangat diperlukan mengingat peran keluarga, khususnya orang tua sangat penting dalam membentuk kepribadian anak berdasarkan ajaran agama. Karena itu nilai-nilai positif yang hendak dikembangkan di sekolah yang juga diprogramkan untuk dikembangkan di lingkungan keluarga, hendaknya merupakan hasil diskusi pihak sekolah dan perwakilan wali murid. Pola kerja sama semestinya diupayakan terus berlanjut sehingga tujuan dari pembelajaran tersebut dapat tercapai dengan baik.

Pembagian tanggung jawab antara orang tua dan sekolah (guru) yang harmonis dapat memberikan keuntungan. Kerja sama dan pembagian tanggung jawab ini dapat dijabarkan dalam bentuk pembahasan program kerja sekolah, sumbangan keahlian, aktif dalam berkoordinasi, memberikan masukan, ide, gagasan bahkan sampai hal yang sifatnya materi seperti sarana prasarana dan pendanaan. Di samping itu, orang tua dapat pula dilibatkan dalam memberikan motivasi belajar kepada siswa dan pelaksanaaan pendidikan di sekolah, tentu saja dengan batas-batas tertentu.

Dari uraian tersebut di atas, nampak jelas bahwa pertemuan guru dan orang tua sangat bermanfaat sekali bagi perkembangan anak. Dengan pertemuan ini guru-guru dapat mengenalkan sekolah kepada orang tua siswa, memperlihatkan dan menjelaskan apa yang terjadi di sekolah sehingga terjadi hubungan yang harmonis antara orang tua dan guru. Kerja sama mendidik anak memerlukan sikap kenal mengenal guru dengan orang tua siswa. Sebaliknya guru melakukan kunjungan rumah.
Manfaat lain yang dirasakan dalam kegiatan ini adalah dengan percakapan orang tua dengan guru akan diperoleh informasi tentang anak, guru berkenalan dengan orang tua, maka guru dapat memahami kelakuan anak sesuai dengan pribadi orang tua, orang tua menghargai guru terhadap pendidikan anaknya dan mempererat hubungan kerja sama. Guru dapat mengenal keadaan dan suasana rumah siswa, karena lingkungan memberi pengaruh besar pada kelakuan anak, guru dapat memberi petunjuk untuk memperbaiki kelakuan anak, dalam hal ini dilakukan dengan kerja sama.

\section{Faktor-Faktor yang Mempengaruhi Penanaman Nilai-Niai Religius}

Beberapa upaya telah dilakukan pihak madrasah di dalam menanamkan nilai-nilai religius pada peserta didik baik melalui proses belajar mengajar di dalam kelas maupun melalui kegiatan keagamaan serta dengan berbagai pendekatan seperti berupaya meningkatkan disiplin beribadah siswa, melalui keteladanan dalam pembentukan Akhlaqul karimah siswa, pembiasaan dalam beribadah, berupaya menegakkan aturan-aturan dan tata tertib madrasah serta pembentukan suasana/lingkungan religius di madrasah dan menjalin kerja sama sekolah dengan orang tua siswa. Akan tetapi, dalam pelaksanaanya beberapa faktor penghambat yang dapat mempengaruhi upaya tersebut. Adapun faktor tersebut berasal dari faktor guru, peserta didik itu sendiri, dan faktor orang tua/keluarga.

Berbagai program-program yang dilaksanakan di madrasah tidak dapat terlaksana dengan baik dan tidak mencapai tujuan yang diinginkan. Hal ini disebabkan karena upaya menanamkan nilai-nilai religius, terdapat beberapa guru kurang memahami strategi pembelajaran yang lebih tepat digunakan, sehingga upaya tersebut masih lemah dan menemui berbagai kendala. para guru lebih banyak menggunakan metode ceramah dan mencatat materi pembelajaran di buku dan di papan tulis.

Rendahnya kemampuan guru agama tersebut tentu akan berpengaruh terhadap keberhasilan pembelajaran terutama di dalam penyampaian materi PAI. Sebagaimana diungkapkan oleh Sholeh $(2008$, p. 33) bahwa kegagalan Pendidikan Agama Islam di seko- 
lah/madrasah disebabkan karena rendahnya kemampuan guru agama dalam memilih berbagai pendekatan dalam proses belajar mengajar.

Apabila dilihat dari penyampaian materi pembelajaran yang dilakukan oleh guru PAI di MANW Pancor, para guru lebih banyak menggunakan metode ceramah dan mencatat materi pembelajaran di buku dan di papan tulis. Kondisi tersebut menggambarkan bahwa guru tersebut menggunakan pendekatan pembelajaran yang berorientasi atau berpusat pada guru (teacher centered approach).

Salah satu dampak pendekatan pembelajaran yang berorientasi atau berpusat pada guru (teacher centered approach) ini yakni mengakibatkan siswa cenderung pasif, perkembangan siswa tidak optimal, pembelajaran tidak efektif, proses belajar mengajar di kelas terkesan hanya sekedar menyampaikan materi semata, dan cenderung tidak memiliki target di dalam proses belajar mengajar. Padahal proses belajar mengajar adalah proses yang bertujuan sehingga pola tindakan guru baik di dalam maupun di luar kelas, harus berorientasi kepada tujuan yang ingin dicapai.

Seorang guru seharusnya tidak hanya menguasai materi pelajaran, tetapi seorang guru harus kreatif dalam perencanaan pembelajaran. Seorang guru harus memiliki kemampuan untuk mendalami nilai-nilai yang merupakan landasan motivasi, etik dan moral dari materi pelajaran yang disusunnya serta memahami konfigurasi nilai-nilai tersebut. Seorang guru harus menguasai teori dan praktik tentang cara dan pendekatan yang tepat dan cermat untuk mencapai tujuan pendidikan.

Di samping faktor guru, upaya penanaman nilai-nilai religius juga dipengaruhi oleh faktor siswa itu sendiri. Seorang siswa meninggalkan salat dikarenakan terlalu asyik bermain bersama teman sebaya atau sepermainannya, sehingga lupa untuk mengerjakan salat. Seorang siswa tidak melaksanakan ibadah puasa atau membatalkan puasa, dikarenakan ada teman sebayanya tidak berpuasa dan juga membatalkan puasa. Uraian di atas menggambarkan bahwa perilaku keagamaan siswa juga dipengaruhi oleh teman sebaya atau sepermainan. Karena itulah, sangat penting bagi seorang remaja untuk selektif di dalam memilih teman sebaya atau teman sepermainan.

Teman sebaya bagi seorang remaja mempunyai peranan yang cukup penting bagi perkembangan kepribadiannya. Pentingnya memilih teman sebaya atau teman sepermainan dapat dipahami dari adanya keinginan menjadi mandiri yang timbul dari dalam diri remaja. Salah satu bentuk kemandirian itu adalah dengan mulai melepaskan diri dari pengaruh orang tua dan ketergantungan secara emosional pada orang tua.

Karena itulah, Islam menekankan pentingnya untuk teliti memilih kawan dan sahabat. Imam Ali bin Abi Thalib (as) berkata, Orang yang menjalin persahabatan setelah teliti dalam memilih sahabat, maka persahabatannya akan langgeng dan kokoh. Dari hadis ini dapat dipahami bahwa persahabatan yang dijalin tanpa dasar pemikiran yang benar akan berakhir buruk.

Terkait dengan faktor orangtua, dari hasil wawancara peneliti dengan dengan guru $\mathrm{BP} / \mathrm{BK}$ bahwasanya kepedulian orang tua bagi pendidikan anak masih kurang baik dalam arti belum begitu mendukung. Hal ini dapat dilihat dari kebanyakan orang tua yang jarang berkumpul di rumah. Orang tua juga jarang memperhatikan kegiatan belajar anak di rumah sehingga anak pun bersikap demikian yaitu jarang belajar dan hanya bermain sehingga semangat belajar anak menjadi berkurang.

Bahkan ada pula orang tua yang tidak pernah sama sekali menemani anak untuk belajar. Membiarkan suasanan rumah yang ribut saat anak sedang belajar da tidak mendukung kegiatan belajar saat anak masih bersekolah. Hal ini dapat menurunkan semangat anak untuk belajar bahkan menghilangkan semangat anak dengan keadaan rumah yang ribut.

Di samping itu pula, orang tua kurang melakukan pengawasan terhadap anak, seperti mengontrol kegiatan anak, sehingga anak melakukan hal-hal yang sesuai dengan apa yang diinginkannya tanpa kontrol dari para orang tua. Kontrol dari para orang tua itu sangat penting karena usia SMA itu keadaan anak masih labil dan perlu pengawasan dari para orang tua. Hal inipula yang mempengaruhi upaya penanaman nilai-nilai religius di madrasah.

Uraian tersebut di atas, terjadi karena kurangnya pengetahuan para orang tua akan pentingnya sikap peduli orang tua terhadap pendidikan anak. Sikap peduli orang tua seperti mewajibkan anak belajar di rumah, meluangkan waktu untuk berkumpul dengan anak di rumah, membicarakan masalah sekolah anak, menemani anak belajar pada saat 
anak belajar, selalu menanyakan perkembangan prestasi anak. Prestasi anak bukan hanya ditanya saat setelah penerimaan rapor, hal ini belum begitu diketahui oleh para orang tua.

Dalam pendidikan, peran orang tua dalam memberikan dorongan cinta kasih sangat diperlukan. Bagaimanapun anak pertama kali dipengaruhi oleh lingkungan keluarganya sendiri termasuk dalam pendidikan anak. Oleh karena itu, orang tua harus lebih peka dalam menunjang pendidikan anak agar anak mampu bersaing di masa sekarang dan masa yang akan datang, karena perkembangan dunia akhir-akhir ini semakin pesat yang mana pendidikan itu sangat diutamakan apalagi dalam mencari pekerjaan.

Salah satu dorongan cinta kasih dalam pendidikan anak adalah sikap peduli orang tua akan pendidikan anak-anaknya. Sikap peduli orang tua terhadap anak ialah sikap orang tua dalam memperhatikan anak, menyayangi anak, menasihati anak, menyediakan waktu untuk ngobrol, menyediakan hati untuk mendengarkan keluh kesah anaknya (Setiyanto, 2005, p.174).

Sikap peduli orang tua bisa mempengaruhi pendidikan anak, baik semangat anak untuk sekolah, keinginan anak untuk belajar di rumah. Sikap peduli orang tua secara tidak langsung dapat menumbuhkan semangat belajar dan sekolah anak. Begitu juga sebaliknya, jika orang tua yang kurang peduli atau kurang menunjukkan sikap pedulinya kepada anak, hal tersebut akan menurunkan semangat anak karena merasa tidak dipedulikan oleh orang tua.

\section{SIMPULAN}

Dari hasil wawancara, observasi dan dokumentasi yang telah diuraikan pada hasil penelitian dan pembahasan, dapat diambil simpulan bahwasanaya Upaya penanaman inilai-nilai religius di Madrasah Aliyah NW Pancor ditempuh melalui beberapa upaya yaitu; Melalui proses belajar mengajar di kelas dan melalui kegiatan keagamaan. Adapun kegiatan keagamaannya meliputi kegiatan membaca Alquran, salat Duha berjamaah, salat Zuhur berjamaah, pelaksanaan Peringatan Hari Besar Islam (PHBI), dan pengkajian kitab kuning. Menggunakan berbagai pendekatan, yakni dengan berupaya meningkatkan disiplin beribadah siswa, melalui keteladanan dalam pemben- tukan akhlaqul karimah siswa, melalui pembiasaan dalam beribadah serta berupaya menegakkan aturan-aturan dan tata tertib madrasah; dan menjalin kerja sama sekolah dengan orang tua siswa.

Selanjutnya, beberapa faktor yang menjadi penghambat upaya penanaman nilainilai religius di kalangan peserta didik yakni berasal dari (1) faktor guru. Hal ini terkait dengan kemampuan guru dalam proses pembelajaran; (2) faktor sarana prasarana madrasah; (3) faktor siswa; dan (4) faktor orang tua siswa. Dalam hal ini, orang tua masih belum peduli terhadap pendidikan anak, kurangnya pengawasan orang tua terhadap anak, serta kurangnya pengetahuan orang tua akan pentingnya pendidikan anak.

Berdasarkan hasil penelitian dan simpulan, kepada beberapa pihak yang memiliki kepentingan, kepedulian dan tanggung jawab terkait dengan upaya penanaman nilai-nilai religius sehingga dalam hal ini pihak pengurus yayasan diharapkan terus melakukan koordinasi dan pengawasan terhadap madrasah-madrasah di lingkungan yayasan guna menemukan langkah-langkah yang tepat untuk membantu madrasah dalam upaya menanamkan nilai-nilai religius peserta didik. Peran serta masyarakat terhadap yayasan perlu ditingkatkan, agar keberadaannya dirasakan lebih memberikan pengaruh yang besar terhadap proses pendidikan anak-anak disekitar yayasan.

Selanjutnya, upaya penanaman nilainilai religius guna meningkatkan keimanan dan ketakwaan serta akhlak siswa harus terus dilanjutkan dengan terus memperbaiki kekurangan-kekurangannya, terus berupaya menemukan terobosan-terobosan baru, serta menyediakan sarana dan prasarana madrasah yang lebih memadai. Madrasah hendaknya terus menjalin kerjasama dengan orang tua siswa. Kerja sama dengan orang tua siswa tidak hanya pada pemenuhan biaya saja, akan tetapi harus dibuat bentuk kerja sama yang jelas antara madrasah dan orang tua, terutama dalam merumuskan dan melaksanakan kebijakan madrasah, pemantauan serta evaluasi kegiatan.

\section{DAFTAR PUSTAKA}

Ajat, S. (2011). Pendidikan agama Islam yang ilmiah dan amaliah. Makalah Pidato Pengukuhan Guru Besar, di Universitas Negeri Yogyakarta. 
Alim, M. (2006). Pendidikan agama Islam. upaya pembentukan pemikiran dan kepribadian muslim. Bandung: Remaja Rosdakarya.

Arikunto, S. (2009). Dasar-dasar evaluasi pendidikan. Cetakan 10 (Edisi revisi) Jakarta: Bumi. Aksara.

Boyce, C. (2006). Monitoring and evaluation -2 . Watertown: Fathfinder Internasional.

Daulay, H.P. (2001). Historisasi dan eksistensi pesantren. sekolah dan madrasah. Yogyakarta:Tiara Wacana.

Dawson, C. (2010). Metode penelitian praktis. Sebuah panduan. Yogyakarta: Pustaka Pelajar.

Depdiknas. (2003), Undang-Undang No. 20 Tahun 2003 tentang Sistem Pendidikan Nasional.

Duryat, M. (2013). Paradigma pendidikan Islam. Yogyakarta: Alfabeta.

Indrakusuma, A. A. (2002). Ilmu pendidikan. Surabaya: Usaha Nasional.

Lickona, T. (1992), Educating for character: How our schools can teach respect and responsibility. New York: Bantam Books.

Miles, M. B. \& Huberman, A. M. (1994). Qualitative data analysis (2nd ed.). Thousand Oaks: Sage Publications, Inc.

Moleong, L. (2001). Metode penelitian kualitatif. Bandung: Rosdakarya.

Muhaimin. (2013). Rekonstruksi pendidikan Islam. Jakarta: PT. RajaGrafindo Persada.

Nata, A. (2003). Kapita selekta pendidikan Islam. Bandung: PT. Angkasa.

Pradja, S., M., (1978). Kamus istilah pendidikan dan umum. Surabaya: Usaha Nasional.

Purwanto, N., (2006). Psikologi pendidikan. Bandung : PT. Remaja. Rosdakarya.

Putro, E. (2012). Teknik penyusunan instrumen penelitian. Yogyakarta: Pustaka Pelajar.

Rachman. M. (1999). Manajemen kelas.
Jakarta: Depdiknas.

Sauri \& Nurdin, (2009), Pengembangan model pendidikan nilai berbasis sekolah, keluarga dan masyarakat. Laporan Hasil Penelitian (Hibah Pasca), Bandung: UPI.

Kuntoro, S. A. (2008), Sketsa pendidikan humanis religius, Makalah diskusi dosen Fakultas Ilmu Pendidikan, Universitas Negeri Yogyakarta.

Setiyanto. (2005). Oang tua ideal dari perspektif anak. Jakarta: Grasindo.

Sevilla, C. G., Ochave, J. A., Punsalan, T. G, Regala, B. P., \& Uriarte, G. U. (1993). Pengantar metode penelitian. Jakarta: Universitas Indonesia Press.

Sholeh. (2008). Bertobat sambil bertobat. Jakarta: PT. Mirza.

Soemarmo, (1998), Pedoman pelaksanaan disiplin nasional dan tata sekolah. Jakarta: Jaya Abadi.

Suryabrata, S. (2005). Pengembangan alat ukur psikologis. Yogyakarta: Andi.

Sutrisno. (2012). Pendidikan Islam berbasis problem sosial. Yogyakarta: Ar-Ruzz Media.

Syukir. (1983) Dasar-dasar strategi dakwah Islam. Surabaya: Al-Ikhlas.

Tafsir, A. (2009). Filsafat ilmu: mengurai ontology. epistemologi dan aksiologi pengetahuan (Cet.4). Bandung: Rosdakarya.

Tafsir, A. (2012). Filsafat Pendidikan Islami: integrasi jasmani. rohani dan kalbu memanusiakan manusia. Bandung: PT. Rosdakarya.

Tanlain. (2006). Dasar-dasar ilmu pendidikan. Jakarta: Gramedia

Tolkhah, I. (2004). Membuka jendela pendidikan: mengurai akar traisi dan integrasi keilmuan pendidikan Islam. Jakarta: PT. Raja Grafindo Persada.

Wina, S. (2009). Strategi pembelajaran berorientasi standar proses pendidikan. Jakarta: Kencana Prenada Media Group.

Zubair, A., C. (1995). Kuliah etika. Jakarta: PT. Raja Gravindo Persada. 